\title{
AGE OF THE POST-RIFT SEQUENCE I FROM THE ARARIPE BASIN, LOWER CRETACEOUS, NE BRAZIL: IMPLICATIONS FOR SPATIO-TEMPORAL CORRELATION
}

\author{
JOÃO CARLOS COIMBRA (1) \\ Departamento de Paleontologia e Estratigrafia, Universidade Federal do Rio Grande do Sul, \\ Av. Bento Gonçalves, 9500, Cx. P. 15001, 91501-970, Porto Alegre, RS, Brazil. \\ joao.coimbra@ufrgs.br \\ TIAGO MENEZES FREIRE (D) \\ Programa de Pós-Graduação em Geociências, Universidade Federal do Rio Grande do Sul, \\ Av. Bento Gonçalves, 9500, Cx. P. 15001, 91501-970, Porto Alegre, Brazil. \\ tiagomenezesfreire@hotmail.com
}

\begin{abstract}
A robust biostratigraphic zonation based on microfossils supports the stratigraphic framework and correlation of the interior basins of the Lower Cretaceous of NE Brazil. This zonation has also allowed correlations with coeval sections in the Brazilian marginal basins and in the Gabon and Congo basins (central-west Africa). These records, consisting mainly of non-marine sediments, were a great challenge with regard to the correlation with the International Chronostratigraphic Chart. Therefore, local stages were used, the most recent being the Alagoas local Brazilian Stage, with which the Post-rift Sequence I of the Araripe Basin is related. Regarding lithostratigraphy, this sequence includes the Rio da Batateira (Barbalha for some authors) and Santana formations, the last one with the famous Crato, Ipubi, and Romualdo members, from the base to the top. Although currently there is a consensus on the age of the Alagoas local Brazilian Stage in the Araripe Basin, recently a new age for at least part of the Post-rift Sequence I was proposed. This new proposal, based on isotopic analysis of Re-Os, arose as a panacea to correlate the Rio da Batateira Formation and the Crato and Ipubi members with the international stages. Surprisingly, their authors, although on the one hand they seem to underestimate biostratigraphic results, on the other they seek to support their proposal from microfossils studied by previous authors, but they do so in an inappropriate way, leading readers to misinterpret their results. Therefore, this paper presents a critical review on the age of the Alagoas local Brazilian Stage in the Araripe Basin and nearby basins, refuting a Barremian age for part of the Post-rift Sequence I.
\end{abstract}

Keywords: Alagoas local Brazilian Stage, biostratigraphy, ostracods, palynomorphs, radiometric ages.

RESUMO - Um robusto zoneamento bioestratigráfico baseado em microfósseis suporta o arcabouço estratigráfico e a correlação dos estratos eocretáceos das bacias interiores do NE do Brasil. Esse zoneamento permite também correlações com seções coevas nas bacias marginais brasileiras e nas bacias do Gabão e Congo (centro-oeste da África). Tais registros, compostos principalmente por sedimentos não-marinhos, foram um grande desafio em termos de correlação com a Tabela Cronoestratigráfica Internacional. Assim, foram empregados andares locais, sendo o estratigraficamente mais alto o Andar Alagoas, com o qual a Sequência Pós-rifte I da Bacia do Araripe está relacionada. Quanto à litoestratigrafia, essa sequência inclui as formações Rio da Batateira (Barbalha para alguns autores) e Santana, a qual está subdividida nos famosos membros Crato, Ipubi e Romualdo, da base para o topo. Embora atualmente haja consenso sobre a idade do Andar Alagoas na Bacia do Araripe, recentemente foi proposta uma nova idade para parte da Sequência Pós-rifte I. Essa nova proposta, baseada em análises isotópicas de Re-Os, foi apresentada como uma panaceia para correlacionar a formação Rio da Batateira e os membros Crato e Ipubi com os andares internacionais. Surpreendentemente, seus autores, embora por um lado pareçam desmerecer resultados bioestratigráficos, por outro buscam embasar sua proposta em microfósseis estudados por outros autores, mas o fazem de forma desacertada, levando os leitores a interpretarem equivocadamente seus resultados. Portanto, esse artigo apresenta uma revisão crítica da idade do Andar Alagoas na Bacia do Araripe e bacias próximas, refutando uma idade barremiana para parte da Sequência Pós-rifte I.

Palavras-chave: Andar Alagoas, bioestratigrafia, ostracodes, palinomorfos, idades radiométricas. 


\section{INTRODUCTION}

The Post-rift Sequence I (sensu Assine, 2007) of the Araripe Basin, consisting of rocks of late Aptian/early Albian age, includes the following lithostratigraphic units, from the base to the top: Rio da Batateira (= Barbalha for some authors) and Santana formations, the later with members Crato, Ipubi and Romualdo (Ponte \& Appi, 1990; Assine, 1992; Arai et al., 2001; Coimbra et al., 2002). The Santana Formation is a world famous Fossil Lagerstätte because its rocks are among those with the greatest variety and abundance of astonishingly well-preserved Cretaceous life forms, including ostracods and palynomorphs. It is the most studied unit of the Araripe Basin, the largest NE Brazilian interior basin that originated during the break-up of the Gondwana Supercontinent (Ponte \& Appi, 1990; Matos, 1992; Valença et al., 2003) (Figure 1). It is composed of predominantly non-marine sediments deposited as a result of various geological events, most of them related to the opening of the South Atlantic Ocean that started from the South. However, according to many authors, marine sedimentation occurred in part of the Santana Formation. In this respect, Arai $(2014,2016)$ defends an influence of the Tethys Sea not only in the interior basins of NE Brazil, but also in the marginal basins, except the Pelotas Basin, which is located south of the geomorphological barrier known as Rio Grande Microcontinent.
The age and paleoenvironments of the lithostratigraphic units of the Araripe Basin have been subject to debate for decades. The work of Ponte \& Appi (1990) made extensive use of biostratigraphic data and sequence stratigraphy for the construction of the first robust stratigraphic framework for this basin. Biostratigraphy based on ostracods and palynomorphs was crucial in reassessing the Brejo Santo and Missão Velha formations, in proposing the Abaiara and Rio da Batateira formations, in the rehabilitation of the Arajara Formation, and in detailing the geological history of the Santana Formation. Notwithstanding, the works of Arai et al. (2001) and Coimbra et al. (2002), who published in detail the biostratigraphy of the Araripe Basin, revealed for the first time a large hiatus in a Brazilian Lower Cretaceous sequence, between the Rio da Serra local Brazilian Stage and Alagoas local Brazilian Stage. Regarding the Post-rift Sequence I, those authors concluded that microfossil distribution strongly suggest that the Alagoas local Brazilian Stage is upper Aptian for the Rio da Batateira Formation and the Crato Member (of the Santana Formation), while the up section, Ipubi and Romualdo members, are upper Aptian/lower Albian, correlating well with the nearby basins of the NE Brazil (see figs. 2 and 3 of Coimbra et al., 2002). More recently, the debate on the age of the Post-rift Sequence I has raised up once again, with Lúcio et al. (2020) introducing a Barremian age for part of this section, centered on Re-Os isotopes. Subsequently, two new biostratigraphic studies were

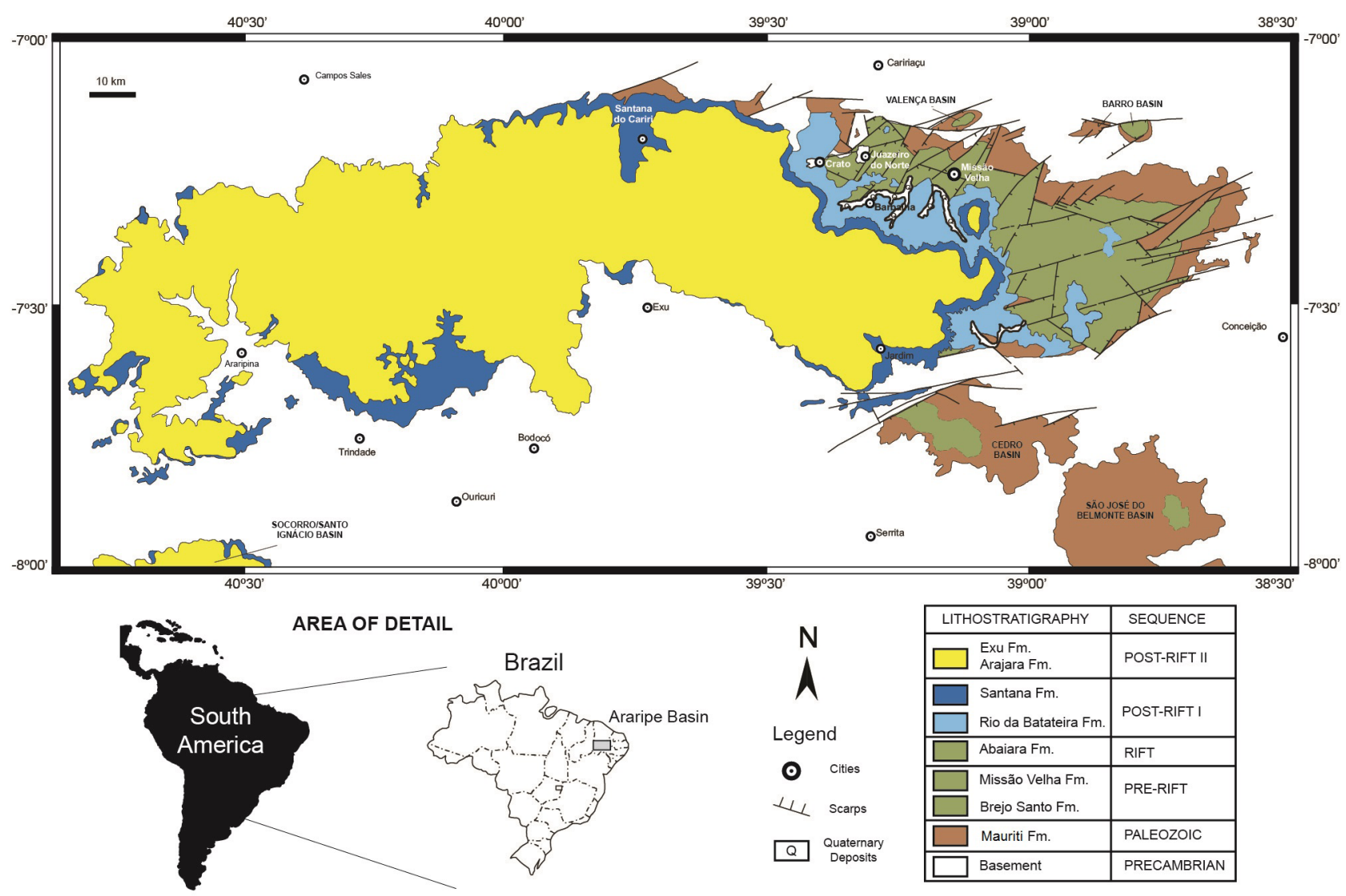

Figure 1. Location map and lithostratigraphy of the Araripe Basin (modified from Assine, 2007). The names of the lithostratigraphic units follow Ponte \& Appi (1990). 
published, one by Arai \& Assine (2020) and the other by Melo et al. (2020). The first concluded that there are no Albian palynomorphs in the Post-rift Sequence I, which corresponds entirely to the Sergipea variverrucata palynozone. Melo et al. (2020), studying ostracods and foraminifers, came to the same conclusion, that is, the sequence in question corresponds to the upper part of the Aptian. In view of this, the present work aims to contribute to this debate, considering biostratigraphic and geochronological analyses, having as a case study the Post-rift Sequence I of the Araripe Basin.

\section{GEOLOGICAL SETTING}

Analysis based on sequence stratigraphy supported by massive micropaleontological dating show that the Araripe Basin has a polycyclic sedimentary history, comparable to that of many intracratonic and marginal basins (Arai et al., 2001; Coimbra et al., 2002; Arai, 2006; and references in them). The Araripe Basin is a Juro-Cretaceous interior basin located in the NE of Brazil, with an approximate area of around $8,000 \mathrm{~km}^{2}$, limited according to the coordinates $7^{\circ} 05^{\text {' }}$ to $7^{\circ} 50^{\prime} \mathrm{S}$ and $38^{\circ} 30^{\prime}$ to $40^{\circ} 50^{\prime} \mathrm{W}$. It rests on Precambrian rocks of the Borborema Province south of the Patos Lineament and presents a complex geological history. The geology of the Araripe Basin and the denomination of its stratigraphic units go back to Small (1913). Almost 60 years later, Beurlen (1971) defined the worldwide famous Santana Formation. Nevertheless, Neumann (1999) and Neumann \& Cabrera (1999) elevated the Santana Formation to the status of Santana Group, with its three members, Crato, Ipubi and Romualdo (from the base to the top), raised to the status of formations. Assine et al. (2014) and Neumann \& Assine (2015) included in the Santana Group the Rio da Batateira Formation (sensu Ponte \& Appi, 1990) or Barbalha Formation (sensu Assine, 1992). This paper follows the lithostratigraphic terminology proposed by Ponte \& Appi (1990) (Figure 2).

The Post-rift Sequence I of the Araripe Basin encompass the Rio da Batateira and Santana formations, while the Postrift Sequence II includes the Arajara and Exu formations (see Assine, 2007 and Assine et al., 2014, paying attention because they used a somewhat different lithostratigraphic terminology from that of Ponte \& Appi, 1990) (see Figure 2 to compare terminology). The Rio da Batateira Formation is represented mainly by fine to medium sandstones, slightly rounded and clayey, with planar or trough cross stratification. Reddish shales and fine conglomerates are interbedded with the sandstones, with a predominant fluvial paleoenvironment (Ponte \& Appi, 1990; Assine, 1992, 2007). The microfossils present in this unit are similar to those found in the Santana Formation, but the palynomorphs indicate a late Aptian age for the Rio da Batateira Formation (Arai et al., 2001; Coimbra et al., 2002, figs. 2 and 3).

The upper Aptian/Albian sediments of the Santana Formation are subdivided into three members as above mentioned. The oldest one is the Crato Member, which is characterized by lacustrine calciferous shales at the base, followed by argillaceous limestones. At the middle of the formation occurs an evaporitic deposit constituted by gypsum and anhydrite intercalated by beds of dark shales, the Ipubi Member. Up section, appears the youngest unit of the Santana Formation, the Romualdo Member, which is composed by shales, marls, limestones and interbedded sandstones. The world famous calciferous concretions of the Araripe Basin, containing mainly amazingly well-preserved fossil fishes, come from the Romualdo Member (see more details in Ponte \& Appi, 1990; Ponte \& Ponte-Filho, 1996; Neumann \& Cabrera, 1999; Coimbra et al., 2002; Assine, 2007; Custódio et al., 2017).

The Crato Member appears just above the clayey sandstones of the Rio da Batateira Formation. Neumann et al. (2003) interpreted the carbonates of the Crato Member as a result of bacterial activity under anoxic conditions, although there is evidence of similar facies derived of chemical sedimentation mechanisms. However, Catto et al. (2016) hypothesize that around $90 \%$ of that carbonate came from organic activity that reduced sulfates, which promoted an atypical concentration of sulfides by biological induction. Varejão et al. (2019), in a study on crustacean taphonomy, called attention to the role of microbial mats in improving the extremely fine fossilization. These laminated carbonates are a Konservat-Lagerstätte that holds astonishingly well-preserved and diverse fossil assemblages with plants, palynomorphs, vertebrates, invertebrates and ichnofossils. Although many authors have studied the fossil record of Crato Member, the book edited by Martill et al. (2007) brings together the state of the art of paleontology in this unit of the Santana Formation.

\begin{tabular}{|c|c|c|c|c|c|c|c|c|}
\hline \multicolumn{3}{|c|}{ Ponte \& Appi (1990) } & \multicolumn{3}{|c|}{ Assine (2007) } & \multicolumn{2}{|c|}{ Assine et al. (2014) } & Sequence \\
\hline \multirow{6}{*}{$\begin{array}{l}\text { Araripe } \\
\text { Group }\end{array}$} & \multirow{2}{*}{\multicolumn{2}{|c|}{$\begin{array}{c}\text { Exu Formation } \\
\text { Arajara Formation }\end{array}$}} & \multirow{6}{*}{$\begin{array}{l}\text { Araripe } \\
\text { Group }\end{array}$} & Exu Fo & ation & \multirow{2}{*}{$\begin{array}{l}\text { Araripe } \\
\text { Group }\end{array}$} & Exu Formation & \multirow{2}{*}{ Post-rift II } \\
\hline & & & & \multicolumn{2}{|c|}{ Araripina Formation } & & Araripina Formation & \\
\hline & \multirow{3}{*}{$\begin{array}{l}\text { Santana } \\
\text { Formation }\end{array}$} & $\begin{array}{l}\text { Romualdo } \\
\text { Member }\end{array}$ & & \multirow{3}{*}{$\begin{array}{l}\text { Santana } \\
\text { Formation }\end{array}$} & \multirow{2}{*}{\begin{tabular}{|c|c|}
$\begin{array}{c}\text { Romualdo } \\
\text { Member }\end{array}$ \\
$\begin{array}{c}\text { Ipubi } \\
\text { Layers }\end{array}$
\end{tabular}} & \multirow{4}{*}{$\begin{array}{l}\text { Santana } \\
\text { Group }\end{array}$} & $\begin{array}{l}\text { Romualdo } \\
\text { Formation }\end{array}$ & \multirow{4}{*}{ Post-rift I } \\
\hline & & $\begin{array}{c}\text { Ipubi } \\
\text { Member }\end{array}$ & & & & & Ipubi Formation & \\
\hline & & $\begin{array}{c}\text { Crato } \\
\text { Member }\end{array}$ & & & $\begin{array}{l}\text { Crato } \\
\text { Member }\end{array}$ & & Crato Formation & \\
\hline & Rio da Batate & Formation & & Barbalha & mation & & Barbalha Formation & \\
\hline
\end{tabular}

Figure 2. Comparison among the most frequently used names for the lithostratigraphic units of the Post-rift Sequence of the Araripe Basin. More details on the proposition of these names in the text. 
The laminated carbonate sequence is compatible with a lacustrine depositional system (Silva, 1986). According to Assine (1990, 1992), the environment was of low energy with the decrease of terrigenous inputs towards the top, and occurrence of algal filaments. The Crato Member lacustrine dark/greenish gray shales and laminated limestones are arranged in a vertical facies series as a transgressive systems tract (see Assine et al., 2014).

The Ipubi Member is represented by evaporites (gypsum) whose genesis has been debated over several decades. The deposits are well developed in the western portion, while in the eastern portion the levels are lenticular and occur interbedded with green or black shales with thin sandy layers and laminated limestone. In addition to the primary and secondary forms of gypsum, laminated and nodular anhydrite also occur (Silva, 1986, 1988). The black shales associated with the evaporites are rich in organic matter and very fossiliferous (e.g. ostracods, fish and carbonized wood). In agreement with Assine (2007), a few authors (e.g. Goldberg et al., 2019) have referred to the Ipubi Member as "Ipubi Layers", arguing that its distribution in the basin is discontinuous. However, as already pointed out by Bobco et al. (2017), the Brazilian Code of Stratigraphic Nomenclature establishes that "A series of small discontinuous masses of rock, with approximately the same character and stratigraphic position, within a formation, can be defined and referred to as a member" (Petri et al., 1986, p. 373, Art. B.6, § 2. ; translated from original, in Portuguese). Therefore, herein we adopted the denomination Ipubi Member (Beurlen, 1971; Ponte \& Appi, 1990) to these rocks as a constituent of the Santana Formation together with the other two members, Crato and Romualdo.

The depositional setting of the Ipubi Member has been interpreted as a coastal environment, susceptible to the relative sea level changes, under arid to semi-arid climatic conditions. The mineralogy, dimensions, nature and geometry of the layers indicate a depositional system similar to those of modern coastal sabkha in South Australia (Assine, 2007; Assine et al., 2014; Bobco et al., 2017; Fabin et al., 2018; Goldberg et al., 2019).

The Romualdo Member, the last member of the Santana Formation, is one of the Fossil Lagerstätte most studied worldwide. In its lower portion, it is characterized by the presence of sandstones interstratified with shales. Up section, the record is transgressive, and the sandstones give way to green shales with ostracods. Towards the top, the shales are darker, culminating with an interval of about $20 \mathrm{~m}$ of dark gray and black shales, rich in organic matter, characterized by the presence of fossiliferous concretions. The level of concretions, which reaches about $5 \mathrm{~m}$ thick in the eastern portion, occurs throughout the basin as a stratigraphic mark, being a register of mass mortality. Concretions enclose a very diverse and abundant paleoichthyofauna and secondarily other fossils, such as turtles, pterosaurs and ostracods (Arai \& Coimbra, 1990; Coimbra et al., 2002; Fara et al., 2005; Assine, 2007; Assine et al., 2014). For a more detailed geology and a list of the Romualdo fossils see Custódio et al. (2017 and references therein).

\section{MICROFOSSIL BIOSTRATIGRAPHY OF THE POST-RIFT SEQUENCE I}

Despite valuable studies by other authors, it was Ponte \& Appi (1990) who established the modern stratigraphic framework of the Araripe Basin. The study performed by those authors was part of a long-term project conducted by CENPES (Centro de Pesquisas Leopoldo Miguez de Mello, at PETROBRAS), which included an extensive geological research of the NE Brazilian Mesozoic sedimentary basins. The biostratigraphy based on ostracods and palynomorphs distributions throughout the sedimentary sequence was fundamental to the new stratigraphic chart of Ponte \& Appi (1990), as we mentioned before. The senior author of this paper participated in that project as a paleomicrontologist, being the detailed biostratigraphic results published only much later by Arai et al. (2001) and Coimbra et al. (2002).

Arai et al. (2001) and Coimbra et al. (2002) identified in the Santana Formation the upper Aptian/Albian ostracod biozone Cytheridea spp. 201/218 and the Sergipea variverrucata and Cicatricosisporites avnimelechi palynozones. The Crato Member (upper Aptian) corresponds to the upper portion of the Aptian Sergipea variverrucata palynozone, while the upper Aptian/Albian Cicatricosisporites avnimelechi palynozone occurs in the Romualdo Member. Regarding the Ipubi Member, most of the samples were sterile, being possible, however, to identify ostracods from the Cytheridea spp. 201/218 biozone. The rare samples with palynomorphs were not diagnostic of biozones, highlighting the absence of Sergipea variverrucata. According to those authors, the most plausible option was to correlate the Ipubi Member with the Cicatricosisporites avnimelechi palynozone. The Rio da Batateira Formation, subjacent to the Santana Formation, although poor in ostracods, allowed the identification of Cytheridea spp. 201/218 biozone, while the abundant palynomorphs characterized the palynozone Sergipea variverrucata. Overlying the Santana Formation, the lithostratigraphic unit corresponding to the Arajara Formation was barren in ostracods. However, through the reevaluation of samples from previous works (e.g. Lima, 1978a-d), Arai et al. (2001) and Coimbra et al. (2002) suggested the correlation with the Cicatricosisporites avnimelechi palynozone, highlighting that the contact between the Romualdo Member and the Arajara Formation is gradual.

The work of Teixeira et al. (2017), an interesting study of palynofacies focused on the paleoenvironments of the Romualdo Member, recorded a few samples containing specimens of Sergipea variverrucata Regali et al., 1974 emend. Regali, 1987. However, the very recent works by Arai \& Assine (2020) and Melo et al. (2020) are the ones that present the most in-depth studies on the age and paleoenvironments of this lithostratigraphic unit.

Arai \& Assine (2020) performed palynological analyzes on 40 samples from a $100 \mathrm{~m}$ thick section known in the literature as 'Sítio Sobradinho', a very complete section of the Romualdo Member. In that work (p. 7) was recorded the indubitable and abundant presence of the palynomorph 
S. variverrucata, as follows: "This species occurs fairly regularly through the studied section, with no systematic concurrence among strata containing Sergipea variverrucata and those containing demonstrably reworked palynomorphs (e.g. Devonian acritarchs and prasinophyceans). Therefore, contrary to Arai and Coimbra (1990), Heimhofer et al. (2008) and Heimhofer and Hochuli (2010), S. variverrucata is regarded here as a genuinely in situ component of the palynoflora". It is also noteworthy that any Albian palynomorph was not found. Consequently, the entire Post-rift Sequence I of the Araripe Basin corresponds to the palynozone Sergipea variverrucata (= P-270 for Petrobras), which determines the upper part of the Aptian in Brazilian basins.

Melo et al. (2020) analyzed the calcareous microfossils of the same outcrop studied by Arai \& Assine (2020), recording the Cytheridea spp. 201-218 ostracode biozone (RT-011 for Petrobras). The identification of 17 species of foraminifera, including abundant "hedbergellids" (Hedbergella and Microhedbergella) and chilostomellids (Gubkinella), among others, is an evidence of a typical late Aptian-early Albian assemblage. In addition, the absence of exclusively Albian species restricts this section to Aptian. In the words of Melo et al. (2020, p. 6), "the first occurrence of Microhedbergella renilaevis marks an important bioevent that represents a major step in the evolution and diversification of the Albian planktic fauna, an event that was not identified in the studied section. Furthermore, the chronostratigraphic positioning of the lithological section studied in the upper Aptian, can be corroborated by the occurrence of Sergipea variverrucata Palynozone P-270, which was identified throughout the Sitio Sobradinho section by Teixeira et al. (2017)".

\section{MICROFOSSILS VS. RHENIUM-OSMIUM ISOTOPE DATA}

Considering that the works of Arai \& Assine (2020) and Melo et al. (2020) were published after that of Lúcio et al. (2020), the present discussion focuses only on the works on microfossils and biostratigraphy available to the last authors.

The Alagoas local Brazilian Stage presents an ostracod assemblage quite different from those of the previous stages even in the genus level, probably due to the environmental changes that occurred in the period, being Aptian/Albian in age (e.g. Arai et al., 2001; Coimbra et al., 2002; Do Carmo et al., 2013; Souza et al., 2017). The species characterize the Cytheridea? spp. 201/218 biozone, the top of which presents a relatively diachronous behavior, as pointed out by Viana (1980). In turn, Regali et al. (1974) and Arai et al. (1989) spotlighted the value of palynozones not only in identifying this local stage, but also in allowing its correlation with the International Chronostratigraphic Chart. The Alagoas local Brazilian Stage contains evaporitic rocks that are a guide horizon for intercontinental correlation, and mark the passage from the sin-rift stage to the proto-oceanic one in almost all Brazilian marginal basins. According to Arai et al. (1989, figs. 3 and 4), until that date there was virtually a consensus that most of this stage corresponds to the Aptian, with only the top of it, which is correlated to the 'Microfloristic Event 7', being of early Albian age.

Since then, the palynology of the Alagoas local Brazilian Stage and its application to biostratigraphy and correlation have received contributions from studies performed in a number of Brazilian basins, both marginal and interior. These studies have corroborated that the microfloristic composition of this stage corresponds to an Aptian/Albian age (e.g. Antonioli, 1998, 2001; Arai et al., 2001; Rossetti et al., 2001; Coimbra et al., 2002; Portela, 2008; Heimhofer \& Hochuli, 2010; Rios-Netto et al., 2012; Portela et al., 2014; Carvalho et al., 2016, 2017; Nascimento et al., 2017). However, in the Araripe Basin, the palynozones identified by Arai et al. (2001) and Coimbra et al. (2002) clearly indicate that in this basin this stage corresponds to the late Aptian/early Albian in age. In this basin, in the rocks corresponding to the Alagoas local Brazilian Stage, only the Sergipea variverrucata and Cicatricosisporites avnimelechi palynozones have been registered, the first being the oldest. Below the Sergipea variverrucata palynozone, typical palynozones of the base of the Alagoas local Brazilian Stage are absent, including the Tucanopollis crisopolensis (= Clavatipollenites crisopolensis) palynozone, which is a marker of the EM-5 Microfloristic Event, that is correlated to the base of the lower portion of the Aptian in Brazilian and African basins (Arai et al., 1989 and references; Ferreira et al., 2020). Teixeira et al. (2017) detected specimens of Sergipea variverrucata at the base and top of 'Sítio Sobradinho', constraining the Romualdo Member age to the late Aptian. Unfortunately, Lúcio et al. (2020) were not aware of that work. Associated with this, there is the absence of the ostracod biozones referring to the local Brazilian stages Aratu, Buracica and Jiquiá, which revealed a large hiatus between the Rio da Serra local Brazilian Stage and the Alagoas local Brazilian Stage (Arai et al., 2001; Coimbra et al., 2002).

Despite the robustness of the Lower Cretaceous biostratigraphic framework in the NE Brazilian basins, Lúcio et al. (2020) diminished the potential of the current zonal scheme in correlating the Alagoas local Brazilian Stage with the International Chronostratigraphic Chart. They performed a geochemical analysis in nine samples of black shales of the Ipubi Member based on Rhenium-Osmium isotope data. Exclusively based on isotopic results, those authors concluded that the absolute age of $123 \pm 3.5 \mathrm{Ma}$ indicates that the black shales were deposited between the latest Barremian/earliest Aptian. In addition, even including the uncertainty of the ReOs age, they proposed that the shales represent the deposition just before the onset of the Oceanic Anoxic Event 1a (early Aptian). Lúcio et al. (2020, p. 8) also concluded that: "The new Re-Os age provides a significant improvement to the previous age determinations of Aptian to Albian (125-100.5 Ma) defined by relative dating age methods (Fig. 3; Coimbra et al., 2002; Tomé et al., 2014)". However, neither Coimbra et al. (2002) nor Tomé et al. (2014) indicated such a wide age interval for the Ipubi Member. Tomé et al. (2014), mainly based on the works of Arai et al. (2001, 2004), both not registered in the references by Lúcio et al. (2020), indicated 
an Aptian/early Albian age for the entire Santana Formation. Heimhofer \& Hochuli (2010), another work not mentioned by Lúcio et al. (2020), proposed a late Aptian age for the Rio da Batateira Formation and the Crato Member, an early Albian age for the Romualdo Member and probably a late Aptian/early Albian age for the Ipubi Member, based on agediagnostic palynomorphs and dinoflagellates recorded below and above the Ipubi evaporites.

According to Lúcio et al. (2020, p. 8), the Romualdo Member (calciferous mudstone and sandstone) and the Ipubi Member (black shales and evaporites) correspond to the Aptian/Albian interval. Down section, the deposits of the Crato Member (calcareous rocks) and Rio da Batateira Formation (sandstone and mudstone) predate the earliest Aptian, that is, both units would be of upper Barremian age. It is important to note that, comparing the ages informed in the text with those indicated in fig. 7 (also on p. 8) of Lúcio et al. (2020), there are some inconsistencies. For example, in fig. 7 (a) the top of the Crato Member is lower Aptian in age, (b) the Ipubi Member is exclusively middle Aptian in age, and (c) the top of the Romualdo Member is no older than the lower Albian. Still on page 8, the authors affirm that the late Barremian age is supported "by both palynological (e.g., Afropollis jardinus, Classopollis classoides) and ostracodal (e.g., Damonella ultima, Damonella tinkoussouensis) assemblages found in Santana Group (Coimbra et al., 2002; Neumann et al., 2003; Tomé et al., 2014; Nascimento et al., 2017), which are the same species found in Late Barremian successions worldwide (Hughes and McDougall, 1990; Bate, 1999; Gómez et al., 2001; Vallati, 2013)". However, none of the species is worldwide distributed, as the authors wrongly reported, neither the microfossils nor the articles correspond to what Lúcio et al. (2020) are claiming, i.e. none of them support a upper Barremian age for the Crato Member and the Rio da Batateira Formation, as follows:

i. Coimbra et al. (2002, p. 696) concluded that the ostracods recovered in the Rio da Batateira, Santana and Arajara formations correspond to Cytheridea? spp. 201-208 biozone. In turn, the palynomorphs of the Rio da Batateira Formation and the Crato Member mark the Aptian Sergipea variverrucata palynozone. With this in mind, it is surprising that Lúcio et al. (2020, p. 2) assert that "In contrast, palynomorphs reported to this group define two palynozones: the Sergipea variverrucata Zone (Barbalha and Crato formations) and the Cicatricosisporites avnimelechi Zone (Ipubi and Romualdo formations; Coimbra et al., 2002). These zones coincide with the interval between the Rio da Serra and Alagoas local stages (Berriasian to Aptian)". This is not true, as these two palynozones are widely recognized as corresponding exclusively to the Alagoas local Brazilian Stage in many Brazilian basins, as also clearly indicated by Arai et al. (2001) and Coimbra et al. (2002);

ii. Neumann et al. (2003, p. 24), using palynomorphs to determine paleoenvironments, recorded that the upper part of Rio da Batateira Formation and the Crato Member represent a lacustrine event in the Araripe Basin, which is "Late Aptian to Early Albian (?) in age", according to them;

iii. Tomé et al. (2014, p. 174) studying ostracods from the post-rift sequence of the Araripe and Jatobá basins, concluded: "Thus, the systematic descriptions were secured, indicating an Aptian/early Albian age for the fauna found in both basins". However, it is noteworthy that the species identified by Tomé et al. (2014, p. 161) as Damonella ultima (Krömmelbein \&Weber, 1971) nov. comb. is clearly not co-specific with Reconcavona? ultima Krömmelbein \& Weber, 1971, as proposed by those authors, being probably a new species. Likewise, the African (Congo Basin) species Damonella? tinkoussouensis Grosdidier, 1967, although bearing some similarity with the species of Tomé et al. (2014) here under discussion, is a distinct species, which seems to have been also the opinion of those authors, as they did not propose a synonymization. Krömmelbein \& Weber (1971, p. 48), briefly discussed the similarities between D.? tinkoussouensis and R.? ultima, such as differences in the contour of the ventral and posterior margins, to which we add that the Brazilian species is significantly larger and, in dorsal view, narrower;

iv. Nascimento et al. (2017, p. 127), in a study on palynomorphs of the Crato Member in the Jatobá Basin, stated: "It is constituted by transitional elements, with representative species of Aptian reaching up to Albian. Regarding analogous deposits of basins abroad, corresponds to the association described by Doyle et al. (1982), for Angola and Nigeria in the African continent, due to the occurrence of some genera, such as Afropollis, and with that described by Müller et al. (1987) for the South American continent (Colombia, Venezuela, Trinidad, Guyana, Suriname) for the occurrence of Exesipollenites tumulus, Reyrea polymorphus, as well as the occurrence of the genus Afropollis" (translated from original, in Portuguese). It is important to highlight that Doyle et al. (1982) carried out an exhaustive work on the genus Afropollis, having demonstrated that the occurrence of its species is restricted to the interval between the early Aptian and the early Cenomanian. It is also noteworthy the work of Carvalho et al. (2017) who interpreted the paleoclimate during the late Aptian based on the study of palynomorphs in the Sergipe Sub-basin (Sergipe-Alagoas Basin). The age of the Angico Member was determined as follows: "In the Angico section, S. variverrucata was not recorded. However, the associated flora (e.g., Afropollis jardinus, Araucariacites australis, Bennettitaepollenites regaliae, Callialasporites segmentatus, Equisetosporites maculosus, Klukisporites foveolatus, Sergipea simplex) also indicates a late Aptian age" (Carvalho et al., 2017, p. 545).

v. Finally, Lúcio et al. (2020) also failed to seek support in works carried out in basins abroad, since the studies cited by them have no direct correlation with those accomplished in the Post-rift Sequence of the Araripe 
and Jatobá basins. Hughes \& McDougall (1987), studying pollens from Barremian and Aptian sections in the southern England, did not recover any specimens of Afropollis jardinus Doyle et al., 1982. Bate (1999), who studied ostracods and stratigraphy of the West African rift system in Gabon, Congo and Angola, was also mentioned by Lúcio et al. (2020) in support of a Barremian age for the Crato Member and the Rio da Batateira Formation. This was because, supposedly, Damonella ultima (Krömmelbein \& Weber, 1971) would be a junior synonym for Damonella? tinkoussouensis Grosdidier, 1967, a wrong proposal that has already been properly discussed above (for more details see item iii just above). Gómez et al. (2001), studying taphonomy and plant paleoecology of the La Huérguina Formation, southwestern Iberian Ranges, Spain, did not mention the genus Afropollis neither the species Classopollis classoides Pflug, 1953 emend. Pocock \& Jansonius, 1961. Vallati (2013), analyzing palynomorphs of the upper portion of the D-129 Formation, Chubut Province, Argentina, proposed an age corresponding to the late Barremian(?)/early Aptian. However, this age is not related to species of Afropollis nor Classopollis, being the first absent in the D-19 Formation, as the author stated on page 242: "The absence of Afropollis in D-129 Formation can be interpreted in evolutive terms, considering that the appearance of this taxon postdates the first record of Tucanopollis crisopolensis in Brazil and Africa (Doyle et al., 1982)". It should also be noted the study performed by Musacchio (1987), based on ostracods and charophytes, which indicated an Aptian age for at least the upper part of the D-129 Formation.

It is also worth noting that, throughout the work of Lúcio et al. (2020), there are inconsistencies regarding the chronological positioning of the Ipubi Member achieved by the Re-Os isotope method, as follows: (i) in the title, abstract and page 9 it is assigned to late Barremian/early Aptian; (ii) in figure 7, to middle Aptian; and (iii) in the conclusions, to the latest Barremian/earliest Aptian. In turn, the upper portion (including laminated carbonates and siliciclastic rocks) of the Crato Member appears in figure 7 perfectly correlated to the early Aptian, while on the same page the authors claim that this lithostratigraphic unit was deposited before the early Aptian, as follows: “..., whereas the Crato (calcareous rocks) and Barbalha (sandstone and mudstone) formations are older than the earliest Aptian (Figs. 2 and 7)" (Lúcio et al., 2020, p. 8).

\section{FINAL REMARKS}

The study of the evolution of a sedimentary basin demands the integration of results obtained by an extensive analytical tool, and, therefore, a wide discussion among geoscientists of different disciplines. Although radiometric dating provides important data to understand stratigraphic frameworks, they should not be seen as a panacea, being overvalued to the detriment of other methodologies applied to basin analysis, for example, biostratigraphy, sequence stratigraphy and structural geology. For this reason, it is surprising that, based only on Re-Os isotopic analysis performed in nine samples, which, as also discussed by Lúcio et al. (2020), but little valued in their conclusions, presented limitations and some discrepant results among the samples, Lúcio et al. (2020) peremptorily proposed drastic changes in the chronostratigraphy of the Araripe Basin, resulting further in serious problems in the spatio-temporal correlations among the NE Brazilian Lower Cretaceous sections.

With regard to the discussion between their results and those arising from the study of microfossils, Lúcio et al. (2020) made a number of mistakes, including misinterpretations of the biostratigraphic and chronostratigraphic results and conclusions drawn by other authors who also studied the Post-rift Sequence I in the Araripe Basin and nearby basins. The support sought by those authors in works from Brazilian and foreign authors based on ostracods and/or palynomorphs, to sustain a late Barremian age for the Crato Member and the Rio da Batateira Formation, is not found in the results and conclusions of the originals.

At least since the studies of Arai et al. (2001) and Coimbra et al. (2002), it is well established that the deposition of the three members of the Santana Formation - Crato, Ipubi and Romualdo - and the Rio da Batateira Formation occurred during the Alagoas local Brazilian Stage. The correspondence of the Alagoas local Brazilian Stage with the International Chronostratigraphic Chart was debated for a long time, being the work of Arai et al. (1989), a study on the chronostratigraphic value of palynomorphs of the Brazilian Lower Cretaceous rocks, a demonstration that this stage is Aptian/early Albian in age, while in the Araripe Basin the absence of some palynozones restricts it to the upper Aptian/lower Albian (Arai et al., 2001; Coimbra et al., 2002; Heimhofer \& Hochuli, 2010).

A precious work ignored by Lúcio et al. (2020) is that of Teixeira et al. (2017), who based on palynomorphs, constrained the Romualdo Member to the upper Aptian. It is also important to note that two biostratigraphic studies published after Lúcio et al. (2020), both in one of the best outcrops of the Romualdo Member, identified palynomorphs (Arai \& Assine, 2020) and foraminifers (Mello et al., 2020) of undoubtedly late Aptian age. Thus, the lower part of the Post-Rift Sequence I in the Araripe Basin cannot be attributed to Barremian, as proposed by Lúcio et al. (2020).

Finally, we reiterate again that the Lower Cretaceous biostratigraphic framework of the basins in Northeastern Brazil, and its correlation with international stages, are quite robust and widely applied within the context of basin analysis, geohistory and sequence stratigraphy. If the equivocated proposal by Lúcio et al. (2020) was correct, the stratigraphy and correlation of these polycyclic basins would have to be deeply reviewed.

\section{ACKNOWLEDGMENTS}

The authors are indebted to two reviewers, C.T. Bergue and $\mathrm{M}$. Arai, for their suggestions that improved the quality 
of the manuscript. The editor A. M. Ribeiro is thanked for her contribution to the final version of the text. The senior author expresses his gratitude to the National Council for Scientific and Technological Development (CNPq) for Grant 305128/2017-5.

\section{REFERENCES}

Antonioli, L. 1998. Bioestratigrafia, palinologia e paleoambientes da seção Aptiana Eoalbiana da Bacia do Ceará, Nordeste do Brasil. Programa de Pós-Graduação em Análises de Bacias e Faixas Móveis, Universidade do Estado do Rio de Janeiro, M.Sc. thesis, $107 \mathrm{p}$.

Antonioli, L. 2001. Estudo palino-cronoestratigráfico da Formação Codó - Cretáceo Inferior do Nordeste do Brasil. Programa de Pós-Graduação em Geologia, Universidade Federal do Rio de Janeiro, Ph.D. thesis, 303 p.

Arai, M. 2006. Revisão estratigráfica do Cretáceo Inferior das bacias interiores do Nordeste do Brasil. Geociencias, 25:7-15.

Arai, M. 2014. Aptian/Albian (Early Cretaceous) paleogeography of the South Atlantic: a paleontological perspective. Brazilian Journal of Geology, 44:339-350. doi:10.5327/Z23174889201400020012

Arai, M. 2016. Reply to the comments of Assine et al. (Comments on paper by M. Arai "Aptian/Albian (Early Cretaceous) paleogeography of the South Atlantic: a paleontological perspective"). Brazilian Journal of Geology, 46:9-13. doi:10.1590/2317-4889201620150046B

Arai, M. \& Assine, M.L. 2020. Chronostratigraphic constraints and paleoenvironmental interpretation of the Romualdo Formation (Santana Group, Araripe Basin, Northeastern Brazil) based on palynology. Cretaceous Research, 116:104610. doi:10.1016/j. cretres.2020.104610

Arai, M.; Carvalho, I.S. \& Cassab, R.C.B. 2004. Bacias sedimentares brasileiras - Bacia do Araripe. Phoenix, 72:10-17.

Arai, M. \& Coimbra, J.C. 1990. Análise paleoecológica do registro das primeiras ingressões marinhas na Formação Santana (Cretáceo Inferior da Chapada do Araripe). In: SIMPÓSIO DA BACIA DO ARARIPE E BACIAS INTERIORES DO NORDESTE, 1, 1990. Atas, Crato, SBP/URCA/DNPM, p. 225-240.

Arai, M.; Coimbra, J.C. \& Silva-Telles, A.C. 2001. Síntese bioestratigráfica da Bacia do Araripe (Nordeste do Brasil). In: SIMPÓSIO SOBRE A BACIA DO ARARIPE E BACIAS INTERIORES DO NORDESTE, 1-2. Comunicações, Crato, SBP/URCA/DNPM, p. 109-117, 122-124.

Arai, M.; Hashimoto, A.T. \& Uesugui, N. 1989. Significado cronoestratigráfico da associação microflorística do Cretáceo Inferior do Brasil. Boletim de Geociências da Petrobrás, 3:87-103.

Assine, M.L. 1990. Sedimentação e tectônica da Bacia do Araripe (Nordeste do Brasil). Instituto de Geociências e Ciências Exatas, Universidade Estadual Paulista, M.Sc. thesis, 124 p.

Assine, M.L. 1992. Análise estratigráfica da Bacia do Araripe, nordeste do Brasil. Revista Brasileira de Geociencias, 22:289-300.

Assine, M.L. 2007. Bacia do Araripe. Boletim de Geociencias da Petrobras, 15:371-389.

Assine, M.L.; Perinotto, J.A.J.; Andriolli, M.C.; Neumann, V.H.; Mescolotti, P.C. \& Varejão, F.G. 2014. Sequências deposicionais do Andar Alagoas da Bacia do Araripe, Nordeste do Brasil. Boletim de Geociências da Petrobras, 22:3-28.
Bate, R.H. 1999. Non-marine ostracod assemblages of the Pre-salt rift basins of West Africa and their role in sequence stratigraphy. Geological Society, London, Special Publications, 153:283-292. doi:10.1144/GSL.SP.1999.153.01.17

Beurlen, K. 1971. As condições ecológicas e faciológicas da Formação Santana na Chapada do Araripe (Nordeste do Brasil). Anais da Academia Brasileira de Ciências, 43:411-415.

Bobco, F.E.R.; Goldberg, K. \& Bardola, T.P. 2017. Modelo deposicional do Membro Ipubi (Bacia do Araripe, nordeste do Brasil) a partir da caracterização faciológica, petrográfica e isotópica dos evaporitos. Pesquisas em Geociências, 44:431451. doi:10.22456/1807-9806.83267

Carvalho, M.A.; Bengtson, P. \& Lana, C.C. 2016. Late Aptian (Cretaceous) paleoceanography of the South Atlantic Ocean inferred from dinocyst communities of the Sergipe Basin, Brazil. Paleoceanography, 31:2-26. doi:10.1002/2014PA002772

Carvalho, M.; Lana, C.C.; Bengtson, P. \& Sá, N.P. 2017. Late Aptian (Cretaceous) climate changes in northeastern Brazil: a reconstruction based on indicator species analysis (IndVal). Palaeogeography, Palaeoclimatology, Palaeoecology, 485:543560. doi:10.1016/j.palaeo.2017.07.011

Catto, B.; Jahnert, R.J.; Warren, L.V.; Varejão, F.G. \& Assine, M.L. 2016. The microbial nature of laminated limestones: lessons from the Upper Aptian, Araripe Basin, Brazil. Sedimentary Geology, 341:304-315. doi:10.1016/j.sedgeo.2016.05.007

Coimbra, J.C.; Arai, M. \& Carreño, A.L. 2002. Biostratigraphy of Lower Cretaceous microfossils from the Araripe basin, Northeastern Brazil. Geobios, 35:687-698. doi:10.1016/S00166995(02)00082-7

Custódio, M.A.; Quaglio, F.; Warren, L.V.; Simões, M.G.; Fürsich, F.T.; Perinotto, J.A. \& Assine, M.L. 2017. The transgressiveregressive cycle of the Romualdo Formation (Araripe Basin): sedimentary archive of the Early Cretaceous marine ingression in the interior of Northeast Brazil. Sedimentary Geology, 359:1-15. doi:10.1016/j.sedgeo.2017.07.010

Do Carmo, D.A.; Whatley, R.C.; Queiroz, J.V.N. \& Coimbra, J.C. 2013. Taxonomy of limnic Ostracoda (Crustacea) from the Alagamar Formation, Middle-Upper Aptian, Potiguar Basin, Northeastern Brazil. Journal of Palaeontology, 87:91-104. doi:10.1666/11-108R.1

Doyle, J.A.; Jardiné, S. \& Doerenkamp, A. 1982. Afropollis, a new genus of angiosperm pollen, with notes on the Cretaceous palynostratigraphy and paleoenvironments of Northern Gondwana. Bulletin des Centres Recherches ExplorationProduction Elf-Aquitaine, 6:39-117.

Fabin, C.E.; Correia Filho, O.J.; Alencar, M.L.; Barbosa, J.A.; De Miranda, T.S.; Neumann, V.H.; Gomes, I.F. \& Santana, F.R. 2018. Stratigraphic relations of the Ipubi Formation: siliciclasticevaporitic succession of the Araripe Basin. Anais da Academia Brasileira de Ciências, 90:2049-2071. doi:10.1590/00013765201820170526

Fara, E.; Saraiva, A.F.; Campos, D.A.; Moreira, J.K.R.; Siebra, D.C. \& Kellner, A.W.A. 2005. Controlled excavations in the Romualdo Member of the Santana Formation (Early Cretaceous, Araripe Basin, northeastern Brazil): stratigraphic, palaeoenvironmental and palaeoecological implications. Palaeogeography, Palaeoclimatology, Palaeoecology, 218:145160. doi:10.1016/j.palaeo.2004.12.012

Ferreira, N.N.; Ferreira, E.P.; Ramos, R.R.C. \& Carvalho, I.S. 2020. Terrestrial and marine palynomorphs from deposits of the pull-apart rift of West Gondwana (Parnaíba Basin, northern Brazil): Biostratigraphy and relation to tectonic events. Journal of South American Earth Sciences, 101:102612. doi: 10.1016/j. jsames.2020.102612 
Goldberg, K.; Preamor, E.; Bardola, T. \& Souza, P.A. 2019. Aptian marine ingression in the Araripe Basin: implications for paleogeographic reconstruction and evaporite accumulation. Marine and Petroleum Geology, 107:214-221. doi:10.1016/j. marpetgeo.2019.05.011

Gómez, B.; Martín-Closas, C.; Méon, H.; Thévenard, F. \& Barale, G. 2001. Plant taphonomy and palaeoecology in the lacustrine Uña delta (late Barremian, Iberian Ranges, Spain). Palaeogeography, Palaeoclimatololy, Palaeoecology, 170:133-148. doi:10.1016/ S0031-0182(01)00232-2

Grosdidier, E. 1967. Quelques ostracodes nouveaux de la Série Anté-Salifère ("Wealdienne") des bassins côtiers du Gabon et du Congo. Revue de Micropaléontologie, 10:107-118.

Heimhofer, U. \& Hochuli, P.A. 2010. Early Cretaceous angiosperm pollen from a low-latitude succession (Araripe Basin, NE Brazil). Review of Palaeobotany and Palynology, 161:105-126. doi:10.1016/j.revpalbo.2010.03.010

Hughes, N.F. \& McDougall, A.B. 1987. Records of angiospermid pollen entry into the English Early Cretaceous succession. Review of Palaeobotany and Palynology, 50:255-272. doi:10.1016/0034-6667(87)90003-0

Krömmelbein, K. \& Weber, R. 1971. Ostrakoden des "NordostBrasilianischen Wealden". Geologisches Jahrbuch, 115:1-93.

Lima, M.R. 1978a. Palinologia da Formação Santana (Cretáceo do Nordeste do Brasil). Instituto de Geociências, Universidade de São Paulo, Ph.D. thesis, 335 p. doi:10.11606/T.44.1978.tde16112015-153709

Lima, M.R. 1978b. Palinologia da Formação Santana (Cretáceo do Nordeste do Brasil). I. Introdução geológica e descrição sistemática dos esporos da subturma Azonotriletes. Ameghiniana, 15:3-4.

Lima, M.R. 1978c. Microfósseis da Formação Exu, Cretáceo do Nordeste do Brasil. In: CONGRESSO BRASILEIRO DE GEOLOGIA, 30, 1978. Anais, Vol. 2, Recife, p. 965-969.

Lima, M.R., 1978d. Estudo palinológico preliminar de um folhelho betuminoso da Formação Missão Velha, Chapada do Araripe. Boletim do Instituto de Geociencias, USP, 9:136-139.

Lúcio, T.; Souza Neto, J.A. \& Selby, D. 2020. Late Barremian/ Early Aptian Re-Os age of the Ipubi Formation black shales: stratigraphic and paleoenvironmental implications for Araripe Basin, northeastern Brazil. Journal of South American Earth Sciences, 102:102699. doi:10.1016/j.jsames.2020.102699

Martill, D.M.; Bechly, G. \& Loveridge, R.F. 2007. The Crato fossil beds of Brazil: window into an ancient world. $1^{\mathrm{a}} \mathrm{ed}$. Cambridge, Cambridge University Press, 625 p.

Matos, R.M.D. 1992. The Northeast Brazilian Rift System. Tectonics, 11:766-791. doi:10.1029/91TC03092

Melo, R.M.; Guzmán, J.; Almeida-Lima, D.; Piovesan, E.K.; Neumann, V.H.M.L. \& Sousa, A.J. 2020. New marine data and age accuracy of the Romualdo Formation, Araripe Basin, Brazil. Scientific Reports, 10:15779. doi:10.1038/s41598-020-72789-8

Müller, J.; Giacomo, E. \& Van Erve, A.W. 1987. A palynological zonation for the Cretaceous, Tertiary, and Quaternary of South America. American Association of Stratigraphic Palynologists Foundation, Contribution Series, 19:7-76.

Musacchio, E.A. 1987. Five Jurassic and Cretaceous nonmarine ostracodal and charophytal associations (calcareous microfossils) from the San Jorge Gulf Basin, Argentina. Zentralblatt für Geologie und Paläontologie, Teil I, 78:839-851.

Nascimento, L.R.S.L.; Tomé, M.E.T.R.; Barreto, A.M.F.; Oliveira, D.H. \& Neumann, V.H.M.L. 2017. Diagnóstico palinoflorístico do poço 2-JNS-01PE, Cretáceo Inferior, Bacia do Jatobá, nordeste do Brasil. Estudos Geológicos, 27:118-134. doi: 10.18190/1980-8208/estudosgeologicos.v27n1p118-134
Neumann, V.H.M.L. 1999. Estratigrafía, sedimentologia, geoquímica y diagénesis de los sistemas lacustres AptiensesAlbienses de la Cuenca de Araripe (Noreste de Brasil). Universidad de Barcelona, Ph.D. thesis, 244 p.

Neumann, V.H.M.L. \& Assine, M.L. 2015. Stratigraphic proposal to the Post-rift I Tectonic-Sedimentary Sequence of Araripe Basin, Northeastern Brazil. In: INTERNATIONAL CONGRESS ON STRATIGRAPHY, 2, 2015. Abstracts, Graz, ICS/IUGS, p. 274.

Neumann, V.H.M.L.; Borrego, A.G.; Cabrera, L. \& Dino, R. 2003. Organic matter composition and distribution through the AptianAlbian lacustrine sequences of the Araripe Basin, northeastern Brazil. International Journal of Coal Geology, 54:21-40. doi:10.1016/S0166-5162(03)00018-1

Neumann, V.H.M.L. \& Cabrera, L. 1999. Una nueva propuesta estratigrafica para la tectonosecuencia post-rifte de la Cuenca de Araripe, Noreste de Brasil. In: SIMPÓSIO SOBRE O CRETÁCEO DO BRASIL, 5, 1999. Boletim de Resumos, Serra Negra, UNESP/IGCE, p. 279-285.

Petri, S.; Coimbra, A.M.; Amaral, G.; Ojeda, H.O.; Fúlfaro, V.J. \& Ponçano, W.L. 1986. Código Brasileiro de Nomenclatura Estratigráfica. Revista Brasileira de Geociências, 16:376-415.

Ponte, F.C. \& Appi, C.J. 1990. Proposta de revisão da coluna litoestratigráfica da Bacia do Araripe. In: CONGRESSO BRASILEIRO DE GEOLOGIA, 36, 1990. Anais, Natal, SBG, p. 211-226.

Ponte, F.C. \& Ponte Filho, F.C. 1996. Evolução tectônica e classificação da Bacia do Araripe. In: SIMPÓSIO SOBRE O CRETÁCEO DO BRASIL, 4, 1996. Boletim, Águas de São Pedro, UNESP, p. 123-133.

Portela, H.A. 2008. Estudo palinológico e palinofaciológico da Formação Santana, Bacia do Araripe, Nordeste do Brasil. Programa de Pós-Graduação em Análises de Bacias e Faixas Móveis, Universidade do Estado do Rio de Janeiro, M.Sc. thesis, $108 \mathrm{p}$.

Portela, H.A.; Antonioli, L.; Dino, R \& Garcia, M.J. 2014. Caracterização palinoflorística e paleoambiental da Formação Santana (Cretáceo Inferior), poço 4-BO-1-PE, Bacia do Araripe, Nordeste do Brasil. Revista Brasileira de Paleontologia, 17:363-372. doi:10.4072/rbp.2014.3.07

Regali, M.S.P. 1987. O gênero Sergipea e a sua estratigrafia no Eocretáceo do Brasil. In: CONGRESSO BRASILEIRO DE PALEONTOLOGIA, 10, 1987. Anais, Rio de Janeiro, SBP, p. 615-623.

Regali, M.S.P.; Uesugui, N. \& Santos, A.S. 1974. Palinologia dos sedimentos meso-cenozóicos do Brasil (I). Boletim Técnico da Petrobras, 17:177-191.

Rios-Netto, A.M.; Regali, M.S.P.; Carvalho, I.S. \& Freitas, F.I. 2012. Palinoestratigrafia do intervalo Alagoas da Bacia do Araripe, Nordeste do Brasil. Revista Brasileira de Geociências, 42:331-342. doi:10.5327/Z0375-75362012000200009

Rossetti, D.F.; Góes, A.M. \& Arai, M. 2001. A passagem AptianoAlbiano na Bacia do Grajaú, MA. In: D.F. Rossetti, A.M. Góes \& W. Truckenbrodt (eds.) O Cretáceo na Bacia de São Luís-Grajaú, Museu Paranaense Emílio Goeldi, p. 101-117.

Silva, M.A.M. 1986. Lower Cretaceous unconformity truncating evaporite-carbonate sequence, Araripe Basin, northeastern Brazil. Revista Brasileira de Geociências, 16:306-310.

Silva, M.A.M. 1988. Evaporitos do Cretáceo da Bacia do Araripe: ambientes de deposição e história digenética. Boletim de Geociências da Petrobras, 2:53-63.

Small, H.L. 1913. Geologia e suprimento d'água subterrânea no Ceará e parte do Piauhy. 2nd ed. Recife, Inspectoria de Obras Contra as Seccas, $80 \mathrm{p}$. 
Souza, D.M.; Piovesan, E.K. \& Neumann, V.H.M.L. 2017. Ostracodes do Aptiano-Albiano da Bacia do Araripe: implicações paleoambientais e bioestratigráficas. Estudos Geológicos, 27:318. doi: 10.18190/1980-8208/estudosgeologicos.v27n1p3-18

Teixeira, M.C.; Mendonça Filho, J.G.; de Oliveira, A.D. \& Assine, M.L. 2017. Faciologia orgânica da Formação Romualdo (Grupo Santana, Cretáceo Inferior da Bacia do Araripe): caracterização da matéria orgânica sedimentar e interpretação paleoambiental. Geologia USP, 17:19-44. doi:10.11606/issn.2316-9095.v17-347

Tomé, M.E.T.R.; Filho, M.F.L. \& Neumann, V.H.M.L. 2014. Taxonomic studies of non-marine ostracods in the Lower Cretaceous (Aptian-lower Albian) of post-rift sequence from Jatobá and Araripe basins (Northeast Brazil): stratigraphic implications. Cretaceous Research, 48:153-176. doi:10.1016/j. cretres.2013.12.007

Valença, L.M.M.; Neumann, V.H. \& Mabesoone, J.M. 2003. An overview on Callovian-Cenomanian intracratonic basins of Northeast Brazil: onshore stratigraphic record of the opening of the Southern Atlantic. Geologica Acta, 1:261-275. doi:10.1344/105.000001614
Vallati, P. 2013. A mid-Cretaceous palynoflora with Tucanopollis crisopolensis from D-129 Formation, San Jorge Gulf Basin, Argentina. Revista Brasileira de Paleontologia, 16:237-244. doi:10.4072/rbp.2013.2.06

Varejão, F.G.; Fürsich, F.T.; Warren, L.V.; Matos, S.A.; Rodrigues, M.G.; Assine, M.L.; Sales, A.M.F. \& Simões, M.G. 2019. Microbialite fields developed in a protected rocky coastline: the shallow carbonate ramp of the Aptian Romualdo Formation (Araripe Basin, NE Brazil). Sedimentary Geology, 389:103-120. doi:10.1016/j.sedgeo.2019.06.003

Viana, C.F. 1980. Cronoestratigrafia dos sedimentos da margem continental brasileira. In: CONGRESSO BRASILEIRO DE GEOLOGIA, 31, 1980. Anais, Balneário Camboriú, p. 832-843.

Received in 24 August, 2020; accepted in 28 November, 2020. 